\title{
A VIDÉKFEJLESZTÉS ÉS A TURIZMUS KAPCSOLATÁNAK RELEVANCIÁJA
}

\author{
Sánta Ádám Kálmán
}

\begin{abstract}
Absztrakt: A vidék fogalmát és lehatárolását, a vidéki térségek újra strukturálódását, valamint differenciálódását évtizedek óta tudományos diskurzusok övezik. Egységesen elfogadott definíciót nem is találunk a vidékre. Ám arra már sokkal pontosabb koncepciók, meghatározások léteznek, hogy egy hanyatló vidéki terület fellendítése hogyan történhet. Számos nemzeti és szupranacionális programot dolgoztak már ki arra, hogy miként lehet revitalizálni ezeket a térségeket. Mivel ma már nincs akkora dominanciája a vidéki térségekben a mezőgazdaságnak és az iparnak, mint az elmúlt évtizedekben, a szolgáltató szektor nyújtotta lehetőségek tudnak fejlődési lehetőséget biztosítani a rurális régióknak.

Jelen írás célja az, hogy a vidékfejlesztés eszköztárát a turizmus felöl közelítse meg. Kontextusba kerül a vidékfejlesztés fogalmának értelmezése, az, hogy miként illeszthető ebbe a turizmus, milyen elönyökkel járhat a vidéki turizmus a leszakadó térségekben és milyen összteljesítményböl részesülhetnek hazánkban a vidéki turizmus által fellendíteni kívánt térségek.
\end{abstract}

\begin{abstract}
There have been scientific discourses for decades about the definition and conceptualization of the rural areas, as well as the re-structuring and differentiation of rural areas. For this, we do not find a uniformly accepted definition. But there are much more precise concepts and modifications for how to boost a declining rural area. Numerous national and supranational programs have been developed to revitalize these regions. As agriculture and industry are not as dominant in the rural areas as they have been in the past decades, the opportunities offered by the service sector can also offer opportunities for developing these regions.

The aim of this article is to approach the toolbox of rural development from the perspective of tourism. The interpretation of the concept of rural development is put into context, how tourism can be involved into this, what benefits can rural tourism bring to the declining rural spaces, and from what total performance can those areas partake in Hungary, that want to be boosted by rural tourism.
\end{abstract}

Kulcsszavak: turizmus, vidéki területek, vidékfejlesztés, vidéki turizmus

Keywords: tourism, rural areas, rural development, rural tourism

\section{Bevezetés}

Magyarország, mint az Európai Unió teljes jogú tagja köteles a közösségi jogszabályokhoz és a közösen kialakított jogrendhez alkalmazkodni. Ehhez kapcsolódva a mindenkori magyar kormányzatnak kötelessége a közösségi fejlesztéspolitikát is betartania. Igaz ez koránt sem olyan egyszerü, mint amilyennek első ránézésre tünhet.

Mivel egy nemzetgazdaság összetett rendszernek tekinthető, nem csupán áruk termeléséből, szolgáltatások nyújtásából áll, így annak fejlesztése igen sokrétü. Pontosan ezért érdemes komplex mivoltában kezelni és odafigyelni az egyes részek közötti kapcsolatok mélységére és sokrétüségére, hiszen egyetlen tényezö megváltoztatásával a teljes rendszer viselkedése is megváltozik és így kihatással lehet a foglalkoztatásra, a termelékenységre, a közszolgáltatásokra, de befolyásolhatja egy ország lakosságának belső vándorlását is (Vicsek, 2003). Ez fokozott figyelmet kíván akkor, ha vidéki területeket kívánunk fejleszteni, hiszen a

DOI: $10.14232 /$ jtgf.2020.1-2.91-109 
vidéki térségek koránt sem biztos, hogy olyan ellenállóak és annyi lábon állnak, mint a városiak.

Alapvetően a vidéki területekre jellemző változatosság, a sokszínüség, ami pontosan tetten érhető az adott térség társadalmi, gazdasági, természeti sajátosságain. Mindezek mellett elmondható az is, hogy a vidéki térségek esetében alacsony a népsürüség és megfigyelhető az is, hogy a vállalkozások, illetve a civil szervezetek száma is jóval alacsonyabb, mint a nagyvárosi térségekben. Ennek ellenére jelentős a vidéken élők és az ott gazdasági, vagy civil jellegü tevékenységet végző szereplők száma (Kis, 2019). Ezek mellett természetesen nagyon fontos szerepet játszanak a vidékfejlesztési szereplök közötti interakciók, kölcsönös kapcsolatok is.

\section{A vidék fogalmának lehatárolása}

A nyolcvanas évek elejéig a mai értelemben vett vidékfejlesztési politika nem létezett, hiszen magáról a vidék fogalmáról sincs egységes kép. A vidék alapvető és egyben legfőbb funkciója a megbízható élelmiszerellátás biztosítása volt (Nemes, 2000). Ebből fakadóan a vidékfejlesztéshez két az elmúlt évtizedekben sokféleképpen megmutatkozó, egyáltalán nem egységes és több szempontból is vitatott fogalom, vagyis a vidék és a fejlesztés társul. Az említett két fogalom kapcsolatainak teljes körü áttekintése és értelmezése meglehetősen bonyolult és nehéz feladat, mivel mindkét fogalomhoz egyaránt kapcsolódik köznyelvi, tudományos és a politikai megközelítés is (Kulcsár, 2017). A vidék fogalmát meghatározni, a már fellelhető értelmezések között konszenzusra jutni és ebből kiindulva egy egységes véleményt kialakítani egészen komplikált feladat. Ehhez persze az is hozzájárul, hogy a két fogalom időben és térben magas fokú diverzitást mutat az eltérő országok, földrészek között, de ez a diverzitás akár egyetlen országon belül is jelentkezhet.

A vidéket értelmezték már az urbánus és rurális területek közötti eltérésként, ahol a lakosok számára elérhető szolgáltatók és közszolgáltatások köre adja a különbség kiindulópontját (Pitblado, 2005), definiálták már egyszerủen a „városi térségek" ellentéteként (Sarudi, 2003). Alapozták már a fogalmat egy térségben mérhető népsürüségre (OECD, 1994, 2011), ám van olyan szemlélet is, amely feleslegesnek tartja a vidék definiálását (Font, 1998).

A legelfogadottabb megközelítés, mégis az OECD (1996) ajánlásai alapján jött létre. A meghatározás során a kulcskérdés a népsürüség (Dax, 1996). Az eljárás alapján elöször regionális szinten különítették el a térségeket egy országon belül. Ha az adott területen $150 \mathrm{fő} / \mathrm{km} 2$ alatt van a népsürüség, akkor vidéki, ha pedig 150 fö/km2 fölött van a népsürüség, akkor városi jellegü területről beszélhetünk. Ezt követően helyi szinten értelmezték a ruralitás kérdését, amelyben sokkal dominánsabb szerepet játszik a népesség eloszlása az adott régión belül, mint maga a népsürüség. Ez alapján beszélhetünk alapvetően vidéki térségekről, ahol a népesség több mint 50\%-a vidéki közösségekben él, közbenső vidéki térségekröl, ahol a népesség aránya a vidéki közösségekben 15 és $50 \%$ között van, illetve elsősorban alapvetően városi területekről. Itt a népesség kevesebb mint $15 \%$-a él a vidéki közösségekben (OECD, 1994; Dax, 1996; Kis, 2011). 
Ez alapján a későbbi fejlesztésekhez 1995-ben Magyarországon is elvégezték a vidéki térségek meghatározását és kategóriákba sorolását (Kovács et al., 2015). Ezt a kategorizálást hazánk esetében kistérségi szinten végezték el. Azóta a kistérségek már megszüntek, ám a járások ugyanazon funkciókat látják el és nagyjából megfelelő méretü területi egységeket tesznek ki, mint korábban a kistérség. A problémája viszont ennek a kategorizálási eljárásnak, hogy csak statisztikai, illetve leíró célokat szolgál, így valójában nem képes a vidékfejlesztési politika számára teljes körü alapot képezni a beavatkozási vagy fejlesztési célterületek meghatározása során (Kis, 2011).

\section{Fejlődés, fejlesztés definiálása}

Ha a fejlődést akarjuk definiálni, mint a vidékfejlesztés másik kérdéses témája, és a legegyszerübb módon értelmezzük, akkor a fejlödés nem más, mint egy olyan irányt adó koncepció, ami elöremozdulást jelent. Haugland és társai (2011) felfogása szerint a fejlődés értelmezése mindig az adott gazdasági, politikai és ideológiai környezettől, viszonyoktól függ, emellett befolyásolják ágazati szempontok is. Hoggart és Buller (1994) értelmezése szerint a fejlődés „csupán” olyan elmozdulását jelent, amely az addig tapasztalható nem kielégítő életfeltételektől az emberileg jobbnak tartott életfeltételek irányába mutat. Ez a folyamat, az átmenet minden szakaszát magába foglalja a felismeréstől az implementálásig, vagyis egy teljes rendszer elemeinek megváltoztatására történő törekvés megvalósulásáig tart. Rendszerelméleti szempontból a fejlődést tulajdonképpen szerkezeti változásként foghatjuk fel (Farkas, 2002). Egy komplex rendszer szerkezeti-fejlödési lehetőségeit determinálja a már müködésben lévő rendszer integráltsági foka, amely az üzemelés során korábban bekövetkezett integrációs és dezintegrációs folyamatok következménye. Ezen integrációs folyamatoknak köszönhető, hogy növekszik a rendszerben fellelhető elemek, szereplök közötti kapcsolatok, összefüggések és kölcsönhatások száma, intenzitása. A fokozott intenzitás miatt erösödik a teljes rendszer strukturáltsága, szervezettsége, sokrétűsége. Minél integráltabb egy rendszer, annál hatékonyabban képes müködni. Ennek jóvoltából a szocioökonómiai típusú rendszerek fenntartása, az ezekhez kapcsolódóan felmerülő menedzsmentköltségek alacsonyabbá válnak. Ám ennek az integráltságnak az az ára, hogy a rendszer veszít a rugalmasságából és kevésbé lesz alkalmas a fejlődésre, az esetlegesen bekövetkező fokozott nehézségek kezelésére (Nemes, 2018).

Persze a fejlődés végbe mehet mesterséges eredetű transzformációk nélkül is, vagyis anélkül, hogy az emberek beavatkoznának a már meglévő folyamatokban bekövetkező változásokba. Ezért célszerü, hogy a tudatos fejlesztések mindig olyan irányú és mértékü beavatkozások legyenek, amelynek a végső célja és eredménye fejlődés lesz (Cernea, 1994).

Véleményem szerint mondhatnánk azt is, hogy a fejlödés az aktuális személyes értékelés tárgya. Viszont mindenképp olyan koncepciónak kell lennie, amely egy kívánatos, a jelenleginél jobb állapot elérésére törekszik. Ehhez meg kell követelni a kivitelező és végrehajtó egységtől egy adott fokú szervezetei koncentrációt és központosítást. Hangsúlyozni kell az alkalmazkodó képességet és nem szabad szem 
elől veszíti azt a tényt, hogy a nem kiszámítható faktorokra adható válaszhoz flexibilitásra van szükség. Vagyis ahhoz, hogy egy kívánt állapotot elérjünk a fejlesztés segítségével, mindenképp rugalmas hozzáállásra van szükség, mivel a nem várt, nem betervezett faktorok azonnali korrekcióra és cselekvésre kell, hogy késztessék a fejlesztés végrehajtóját.

\section{Helyi fejlesztés, mint vidékfejlesztés?}

Jogosan merül fel tehát a kérdés, hogy ezek alapján mi is a vidékfejlesztés. Ezért megpróbáltam körbejárni a vidékfejlesztés fogalmát. Moseley (2003) értelmezése szerint a vidékfejlesztést a vidéki vagy vidékies jellemzőkkel bíró térségek helyi fejlesztéseként definiálhatjuk. Erre alapozva pedig a helyi fejlesztést olyan lokális szinten megvalósított fejlesztésként, melynek az alapvető célja nem más, mint a lokálisan felmerülő problémák, kérdések kezelése. A koncepció, miszerint a helyi szereplök részvétele és a helyi fejlesztés a vidéki területek fejlesztésekben szükségszerü, már az 1990-es években részévé vált a vidékfejlesztéshez kapcsolódó fogalomkörnek (Ellis-Biggs, 2001). Walsh (1996) felvetése alapján egy helyi fejlesztés sokkal több annál, mint az adott ország központi döntéshozatali és végrehajtási szerveinek felülről lefelé irányuló szervezett beavatkozási stratégiái és azok helyi szinten történő implementálása, mivel az így végrehajtott intézkedések koránt sem fektetnek kellő hangsúlyt a koordinációra vagy az integrációra. Ebből fakadóan a helyi fejlesztés, nem csak egy egyszerü válaszreakció a felmerülő problémákra és nehézségekre, hanem egy sokkal mélyrehatóbb felelet, ami az integratív megközelítésre, a szereplők közötti koordinációra, a szubszidiaritásra és a hosszú távú fenntarthatóságra alapszik.

Moseley (2003), Douglas (2005) és Healey (2015) alapján öt fontos érv hozható fel a helyi fejlesztések mellett:

- a vidéki térségek alapvetően sokszínüek és változatosak,

- a felmerülő problémákat helyileg lehet a legpontosabban definiálni és azokra multidimenzionális módon kell megoldásokat adni,

- a fejlődés eléréséhez szükséges a helyi erőforrások azonosítása és bevonása a folyamatokba,

- azok a fejlesztési projektek, amelyeket a helyi erőforrásokra alapoznak hosszú távon stabilabb és fenntarthatóbb fejlődést eredményeznek,

- a lokális fejlesztések segítik a védekezést a globalizáció káros hatásaival szemben és hozzájárul a helyi társadalom fejlődéséhez.

Hazánkban Erdei (1971), majd az ő munkássága alapján Csatári (2004) is úgy vélekedett, hogy a területi és az eltérö térségekben folytatott életforma differenciáltsága miatt a vidék és a város viszonyának kell a vidékfejlesztés koncepciók kiindulópontjának lennie. Ebböl fakadóan nem lehet elfogadni a korábbi, kizárólag mezőgazdaság központú megközelítéseket, annak ellenére, hogy az agráriumnak is jelentős szerepet kell kapnia a vidék fogalmi sajátosságainak meghatározásában.

$\mathrm{Az}$ évek során a vidékfejlesztés értelmezésében bekövetkezett szemléletváltásokat fellelhetjük a vidékfejlesztési politikákban, stratégiai 
dokumentumokban is (Ellis-Biggs, 2001). Ma már ezekben a dokumentumokban a vidéki területek versenyképességének növelése a cél, mivel ez jelentősen befolyásolja az országok gazdasági teljesítményét is.

Ennek kapcsán jelentette meg az OECD 2018-ban a Rural Policy 3.0 - A Framework For Rural Development címü irányelv jegyzetét. Az OECD által kialakított új vidékfejlesztési koncepció, a „Vidékpolitika 3.0”, olyan komplex szerkezetként értelmezi a vidékfejlesztést, amelyet a nemzeti kormányok eszközként hívhatnak segítségül a vidéki térségek fejlesztésében. Ez a „Vidékpolitika 3.0” az OECD által 2006-ban meghirdetett új „vidéki paradigma” továbbfejlesztett és kiszélesített változata. Ebben a vidékfejlesztést partnerségalapú megközelítésként értelmezik, aminek a középpontjában a helyi kapacitások és képességek javítása áll, azért, hogy ösztönözzék az alulról felfelé irányuló fejlesztési kezdeményezések megszületését és növeljék a felmerülő javaslatok megvalósításában a helyi közösség részvételét (OECD, 2016). Ezzel a vidékről, a vidéki területek lehetőségeiről és kihívásairól kapcsolatban egy új szemléletet, gondolkodási keretet szorgalmaznak, továbbá egy új irányból igyekeznek megközelíteni a nemzeti kormányok szerepét a fejlesztési törekvések és erőfeszítések kidolgozásában, támogatásában és megvalósításában (OECD, 2018). A tervezet fő célja tehát nem más, mint az, hogy egy új vidékfejlesztési politika gyakorlati alkalmazásával növelni lehessen a vidék versenyképességét és termelékenységét, annak érdekében, hogy a vidéki területek társadalmi, gazdasági és természeti környezeti jóllétében minőségi javulás következzen be.

Természetesen hazánkban is több kapcsolódó terület-, gazdaság- és vidékfejlesztési koncepció készült az elmúlt években. Ennek oka, hogy a Magyarországon tapasztalható nagyfokú területi gazdasági és társadalmi különbségek mérséklése iránti igény évtizedek óta érzékelhető (Horváth, 2003). A társadalmi egyenlötlenség, a regionális fejlettségi különbségek a rendszerváltozást követően a piacgazdaságba való átmenet részeként megvalósuló szerkezetátalakítás után nem csökkentek az akkori elvárásoknak megfelelően, hanem tovább mélyültek (Németh et al., 2014). Bár az évek alatt a helyzet stabilizálódott, ám ebből fakadóan hazánkban a vidéki területek fejlesztésével kapcsolatos kérdések és az azokra adott megoldási javaslatok iránti érdeklődés hosszú ideje jelentősnek tekinthető.

Számos jogszabályt és kormányzati, miniszteriális szintű programot kidolgoztak, amelyeket már az 1990-es évek óta korábban az EGK, majd az EU forrásaival is kiegészítettek. Ilyenek voltak „A területfejlesztésről és a területrendezésröl szóló 1996. évi XXI. törvény”, a Nemzeti Vidékfejlesztési Terv 2004-2006, a Közép-Dunántúli Régió Regionális Stratégiai Program 2007-2013, az Agrár- és Vidékfejlesztési Operatív Program, a Helyi Vidékfejlesztési Stratégia, és ilyen a jelenleg érvényben lévő Nemzeti Fejlesztés 2030 - Országos Fejlesztési és Területfejlesztési Koncepció is.

Ezekben a stratégiai dokumentumokban különböző irányokat jelöltek ki azért, hogy a vidéki területek képesek lehessenek első lépésként külső források bevonásával, ám hosszú távon önálló módon saját leszakadásuk megállítására. Ezek között a mezőgazdaság kapott kiemelt szerepet, ám egy szektorhoz, vagyis a 
mezőgazdasághoz kötni a vidékfejlesztés területét és forrásait, helytelen volna (Kulcsár, 2018). Ennek az egyoldalúságnak a feloldása több irányból is megközelíthetö (Janvry-Sadoulet, 2007). Olyan területek is szolgálhatják egy vidéki térségek fejlődését, mint például az újraiparosítás, a civil és környezetvédelmi szervezetek térnyerése, az állami decentralizációnak és a szubszidiaritásnak köszönhetően vidéken megjelenő újabb közigazgatási, gazdasági funkciók ellátásához szükséges munkák növekedése, illetve az elmúlt években az egyre növekvő szerepet kapó turizmus fejlesztése is, mint egyfajta alternatíva a vidéki területek fejlesztésének eszköztárában.

Összességében tehát elmondhatjuk, hogy a vidékfejlesztés mindenképpen egy olyan multidimenzionális folyamat, amely egy adott lakóterületen élő népesség létszámára alapszik. Figyelembe veszi az ott élő lakosság igényeit, képességeit, társadalmi interakcióit, bevonja őket a fejlesztési tervezetek kidolgozásába és megvalósításába azért, hogy hosszú távon fenntartható, a rendelkezésre álló környezeti erőforrásokat nem túlhasználva, magasabb életszínvonalat biztosítson a térségben élöknek megteremtve a lehetőségét annak, hogy a lakosság ne kényszerüljön a fejlettebb területek irányába történő elvándorlásra.

Ehhez kapcsolódóan az a konzekvencia szürhető le, hogy a vidékfejlesztéssel foglalkozó szervezetek, szakemberek olyan koncepciókat, azok megvalósításához pedig olyan programokat dolgoznak ki emberi, szellemi, pénzügyi és anyagi forrásokat allokálva, amelyek segítségével az adott térségben élők életminőségében tapasztalhatóan elöre irányuló elmozdulás valósul meg. Végső soron tehát a vidékfejlesztés nem más, mint a helyben elérhető erőforrások értékének növelése, azok felhasználása egy élhető környezet megteremtésére a helyi érdekeltek és szereplők bevonásával, mozgósításával.

\section{A turizmus, mint a vidékfejlesztés lehetséges eszköze}

Ebben a fejezetben arra kerestem a választ, hogy a vidékfejlesztés miként használhatja fel és miként illesztheti bele a turizmust saját eszköztárába a helyi lakosság érdekében.

A kérdés jelen esetben az, miként is kapcsolódhatnak a turisztikai beruházások, fejlesztési programok a vidékfejlesztéshez. Tulajdonképpen a turizmus már hosszú ideje szolgálja globális és lokális szinten is a vidékfejlesztést, ami az elmúlt évtizedekben hazánkban is egy kiemelt eszközzé vált, komoly szerepet betöltve azokban a hátrányos helyzetü térségekben, ahol társadalmi-gazdasági téren más típusú gazdasági tevékenységre kevés a lehetőség (Marton et al., 2016). A turisztikai szektor akár a már rendelkezésére álló erőforrásainak hatékony felhasználása révén, képes részt venni egy adott térség gazdaságfejlesztési folyamataiban, ha ehhez hosszú távú terveket dolgoznak ki, növelheti a vizsgált térség jövedelemtermelö képességét, ami elösegítheti a helyi gazdaság és egyúttal a nemzetgazdaság fenntartható fejlődését is (Varga-Nagy, 2016).

Természetesen ez a tervezés sokkal többről szól, mint a már meglévő vonzerők bemutatása. Elsősorban azért, mert a turisták számára értékesített termékek egy folyamat eredményeképpen jönnek létre, amely nélkül koránt sem garantált a termék 
sikeressége. Ennek az egész folyamatnak az alapját a vonzerők adják, amely vonzerőkből attrakciót kell formálni, az attrakciókat az elérhető szolgáltatásokkal egybekötve pedig versenyképes turisztikai termékké kell szervezni. A szolgáltatási elemek között a turista vásárlási döntései fogják megteremteni a kapcsolatot (Jancsik, 2007). Ezt a turisztikai terméket kell végül értékesíteni a „fogyasztóknak”, vagyis a turistáknak, olyan módon, hogy a klasszikus termékek esetéhez hasonlóan egy élethosszig tartó lojalitást tudjunk kialakítani a fogyasztó és a felkeresett desztináció között (Oppermann, 2000). Ennek a lojalitásnak persze többnek kell lennie, mint a korábbi látogatások összegzett pozitív tapasztalatai. A turizmusnak, mint iparágnak az utazók által nyújtott vásárlási előzmények és a felmerülö „újravásárlási szándék”, vagyis a desztináció újbóli meglátogatása szolgáltatnak információt, amelyekre alapozzák majd a fejlesztési irányokat.

A turisztikai desztinációk tervezéséért és menedzseléséért felelős személyek könnyedén felismerik azokat a tényezőket, amelyek növelik a desztináció iránti lojalitást. Ennek köszönhetően képesek meghozni azokat az intézkedéseket, amelyek lehetővé teszik ennek a hüségnek az erősítését, a fogyasztók tudatosságának növelését, így válva képessé a turisztikai kereslet befolyásolására. Azok a turisták, akiknek a szolgáltatásminőséggel kapcsolatban magasabb elvárásaik vannak, ezzel egyidőben képesek felismerni a szolgáltatásminőség magas szintjét, az adott desztinációhoz pozitív imázst társítanak, mindezek mellett elégedettnek mutatják magukat a turisztikai élménnyel kapcsolatban, ajánlják a desztinációt másoknak és egyben hajlandóak arra, hogy ismét ellátogassanak az adott fogadóterületre, azok, lojális látogatóknak tekinthetőek (Cossío-Silva et al., 2019). Ha ezek a lojális turisták a statisztikailag mért átlagos tartózkodási időhöz képest több vendégéjszakát töltenek a desztinációban, akkor a desztináció úgynevezett „magas teljesítményü” turistákkal rendelkezik. A magas teljesítményü turisták által elköltött pénz adja a helyi szolgáltatók, így a fogadótérség jövedelmezőségének alapját. Ebbe a jövedelmezőségbe beleértünk minden olyan a jelentkező kereslet miatt képződő, a turizmussal közvetlen kapcsolatban álló ágazatok által nyújtott háttér-,,ipart”, amely biztosítja a turizmust kiszolgáló tevékenységeket (Nemes, 2008; Virág, 2016). Ennek köszönhetően a turisták fogyasztása túlmutat a turizmus ágazatain, és pozitív hatással bír más nemzetgazdasági ágazatokra, például a turisták által elfogyasztott élelmiszerkeresleten keresztül élénkíti a mezőgazdasági termelést is. Ezzel lényegében a desztináció képes pótolni a kiemelt turisztikai időszakokban tapasztalható, máshol üdülő rezidensek miatt visszaeső forgalmat.

A turizmus fenntartható fejlödésének érvényesítése azonban éppen a globalizáció ellen ható folyamatokat indukál (Michalkó-Vízi, 2001). Az elmúlt két évtizedben a turizmusfejlesztés egyik kiemelt céljává vált, hogy a helyi és regionális értékeket megőrizzék, és azokból formáljanak, fejlesszenek piacképes termékeket. Erre azért van szükség, mert a turisták többsége szeretné a hétköznapok egyhangúságát megtörni, saját látásmódját kitágítani ismereteik bővítésével olyan desztinációkban, amelyek saját vonzerejük környezetét autentikus módón őrzik meg. Ebböl fakadóan a turizmus ma már a globális élménykeresés és egyben az egyéneknek az önkiteljesedés lehetőségét is jelenti, ahol a megszerzésnek és a 
megismerésnek minimális korlátai vannak. Ez a megismerés és kiteljesedés, a hétköznapokból való kitörés iránti vágy az, ami az iparilag, vagy mezögazdaságilag kevésbé fejlett térségek jövedelemtermelő képességének növelésében segíthet. Ennek a növekedésnek az elérését, a tevékenységek meghatározását, a tervezést, kialakítást és bizonyos szintig a turisztikai fejlesztések kivitelezését segíti a desztináció menedzsment szervezet.

Mivel Magyarországon a turisztikai régiók nehezen értelmezhetőek, ezért a turizmuspolitikájuk leginkább a régiós és helyi turizmusirányítás (közvetve a területfejlesztés) szintjén nyilvánul meg (Michalkó, 2002). Annak ellenére, hogy a régiók turizmusát képviselő szervezetek megfelelő szakmai kompetenciákkal rendelkeznek, területi jogosítványaik, eszközeik és forrásaik hiányosságai miatt nem mindig képesek a hatályos turizmuspolitika kivitelezésére. Igaz ez koránt sem jelenti azt, hogy az említett szervezetek által végzett munka hatékonysága megkérdőjelezhető lenne. Sőt, inkább arra mutat rá, hogy a hazai turizmus területileg nehezen értelmezhető rendszerében nagy szükség van a központi koordinációra, ám ezzel egy időben a tervezési, döntési és végrehajtási jogkörök decentralizálására is. Ezen a ponton kapcsolódnak a helyi szintü szinergiák a fejlesztésekhez.

Egy desztináció menedzsmentje által, a fejlesztések során Buhalis (2000) szerint 5 fö érintettet, vagyis stakeholdert különíthetünk el: (1) a turistákat, (2) a köz- és magánszférát, (3) az utazásszervezőket, (4) a turisztikai vállalkozásokat, végül, de nem utolsó sorban (5) a fogadó közösséget. Ezen csoportok között kell egy harmonikus együttmüködést létrehozni, hiszen mind az öt szereplő érdekelt abban, hogy a végrehajtandó turisztikai fejlesztésekkel saját régiójuk gyarapodjon. Magyarországon szintén öt eltérő stakeholder csoportot különböztetünk meg, ám az általános nemzetközi gyakorlathoz képest ez némi eltérést mutat (Marton et al., 2016). Hazánkban ezek a csoportok (1) a turisták, (2) a turisztikai vállalkozások, (3) a kapcsolódó szolgáltatók és termékek, (4) az attrakciók és helyi események nonprofit müködtetői illetve (5) a települési önkormányzatok. A kooperációt azért kell megteremteni, mert egy turisztikai desztináció komplex hálózatnak tekinthető, amelyben nagyszámú szereplő érintett. Ebböl fakadóan együttmüködve kell elöállítaniuk a turisztikai szektorban értékesített különböző termékek és szolgáltatások választékát (Gunn, 1994; Pearce, 1989; Hu-Brent Ritchie, 1993; Ramirez, 1999; Buhalis, 2000; Murphy et al., 2000). A turisták magát a desztinációt egyetlen egységnek érzékelik, amely egy integrált élményt, vagy komplex turisztikai terméket kínál számukra (Buhalis, 2000; Murphy et al., 2000). Valójában az élmény-, vagy termékelemek, amiket létrehoznak és összeállítanak, majd a turisták számára értékesítésre kínálnak, különböző egyéni szereplők saját, egyéni teljesítményei. Így az egyes, különálló szereplök sikere, ugyanúgy, mint ahogy az egész desztináció sikere is, a hatékony együttmüködésnek, a különálló vállalatok által birtokolt erőforrások megosztásának és integrációjának, illetve az belőlük elöállított áruknak és szolgáltatásoknak a függvénye (Beritelli et al., 2007; Rodríguez-Díaz-Espino-Rodríguez, 2008).

Az együttmüködésen túlmenően a pénzügyi segítség és a szellemi tökeinput is kiemelten fontos a hosszú távú növekedéshez. Ahhoz, hogy a turizmus a növekedés 
katalizátora legyen egy fejletlenebbnek tartott területen, potenciálisan a leghatékonyabb mód az, ha a vidéki lakosság turizmus által nyújtott új lehetőségekre adott reagálási készségét fejlesztik (Ribeiro-Marques, 2002). Mivel a társadalmi, gazdasági, környezeti, vagy a kulturális elemek bárminemü hiánya befolyásolja a vidéki területek fejlődését, csak a fizikai, társadalmi, gazdasági, helyi és a kreatív rendszerek közötti együttmúködés tudja a vidéki területek fenntartható fejlődését biztosítani (Akgün et al.,2015). Ezek mellett pedig szükséges még a konzisztens, belső ellentmondásoktól mentes országos koncepció, ami megteremti a turisztikai fejlesztések és az és a helyi turizmusban potenciálisan érdekelt szereplők közötti kapcsolatot. Természetesen a helyi sajátosságokra alapozva több tényezö is szükséges lehet még ahhoz, hogy egy vidéki térség egy fejlődő pályára kerüljön a turizmus segítségével. Elsősorban tisztában kell lenni azzal, hogy a vidéki térségekben elérhető desztinációk turisztikai kínálata főleg a belföldi turisták körében és bizonyos termékek esetén néhány külföldi (föként regionális szomszéd) országban versenyképes. Az aktuális hazai desztináció fejlesztési koncepciót és a Nemzeti Turizmusfejlesztési Stratégiát is ennek jegyében alakították ki és a belföldi kereslet élénkülésének köszönhetően idővel nemzetközileg is versenyképessé válhatnak az érintett térségek (MTÜ, 2017). Ebben segítséget jelenthetnek a határmenti együttmüködések is. Megfigyelhető, hogy a Közép-európai régió országainak Európai Unióhoz való csatlakozása pozitív hatással volt a határokon átnyúló turizmusra, így a hanyatló határ menti térségek életére is. A Schengeni határok keleti irányú eltolódása és ezzel egy időben a korábbi értelemben vett államhatárok, illetve a határellenőrzések megszünése elösegítette a közös turisztikai partnerségek kialakítását. Negatív hatások és nehézségek elsősorban olyan országok közötti határterületeken merülnek fel, amelyek valamilyen okból kifolyólag nem tudnak, vagy nem akarnak csatlakozni az Európai Unió tagállamai közé (Dávid et al., 2011). Ilyenek például az EU Ukrajnával, Szerbiával vagy Fehéroroszországgal határos területei.

Igaz a felmerült lehetőségek, elért eredmények koránt sem biztos, hogy a várt eredményeket fogják hozni. Liu, Nijkamp és Lin (2017) alapján a városi-vidéki kettős gazdasági szerkezetből, a turizmus növekedéséből és a turizmus regionális gazdaságra gyakorolt kölcsönhatásaiból az alábbi következtetésekre lehet jutni:

- A turizmus térnyerése alkalmas arra, hogy csökkentse a város és vidék között kialakult gazdasági, társadalmi különbségeket.

- A városi-vidéki gazdasági kettősség a turizmus gazdasági jelentőségére gyakorolt erős negatív mérséklő hatással van. Amellett, hogy a duális gazdasági szerkezet növeli a város-vidék közötti egyenlötlenséget, ez a kettősség gyengíti a turizmus által kifejtett pozitív hatások erejét is.

- A tudatos turizmusfejlesztésnek sem biztos, hogy élénkítő hatása van egy gazdaság növekedésére, sőt, lehetséges, hogy negatív hatásokat fejt ki abban az esetben, ha a régión belüli egyensúly hiánya túlzottan magas fokú. 


\section{Vidéki turizmus, mint egy lehetséges fejlesztési eszköz}

A vidékfejlesztés szempontjából vidéki turizmus mindenféle turisztikai tevékenység, amely vidéki környezetben zajlik és illeszkedik a vidékfejlesztés céljaihoz (Kovács, 2000).

Az olyan minőségben magas és autentikus módon megvalósított szolgáltatások, amelyeket a vidéki területeken élő helyiek üzemeltetnek, és a vidék valós élményét ígérő falusi turisztikai szolgáltatásokat kínálnak az említett területek fejlődéséhez, a területi különbségek csökkenéséhez járulnak hozzá. Emellett a vidéki városok esetében, azok turizmusának fejlesztésével az élhetőség megörzése és javítása kerül kiemelten fontos szerepbe a vidéki turizmussal (Magyar Turisztikai Ügynökség, 2017). A turisztikai fejlesztések segítségével a magyar vidéki turizmus célja hosszú ideje az, hogy feloldja a turizmus területi koncentráltságát, munkahelyeket teremtsen, támogassa a vidékfejlesztési programok megvalósítását és segítse a helyi lakosság megtartását (Magyar Turisztikai Hivatal, 2005).

Mivel a mezőgazdasági modernizáció miatt a vidéki háztartások innen származó jövedelme csökken, a turizmus számos térségben, mint egyetlen jövedelempótló tevékenység jelentkezik. Így az elmaradottabb és magasabb munkanélküliségi rátával rendelkező területek lakosságának életminőségére is pozitív hatással lehet, ha fejlesztik a turizmust. Azonban figyelembe kell venni, hogy turizmusfejlesztés csak a megfelelő adottságokkal és feltételekkel rendelkező területeken indokolt. Mivel a fejlesztési koncepciók általában felülről lefelé terjednek, így a tervezés során a kormányzatoknak tisztában kellene lenniük azzal, hogy a gazdaságpolitikájuk nemcsak a makroökonómiai változókat befolyásolják, hanem a turisztikai keresletet is. Ezért a turisztikai fejlesztések az egész világon az egyes országok gazdaságpolitikájától függenek és bármilyen gazdaságpolitikai következetlenség hatással lehet nemcsak saját, de más országok turisztikai bevételeire is (DemirGozor, 2018).

Mivel a vidéki térségek kimaradnak, vagy sokkal kisebb arányban részesülnek egy ország fejlődéséből, eredeti adottságaikat megőrizték. Ez komoly előnyt jelent a turizmus számára, mivel ezek az adottságok az emberek által korábban nem ismert vonzerőként jelentkeznek és egyúttal alkalmasak arra, hogy a turizmus fokozta túlzott területi centralizációt feloldják (Barke, 2004). Azok az attribútumok, amelyekre a vidéki területek építhetnek, valójában csak mérsékelt vonzású adottságok (Gartner, 2004). Eltérő összetételben, ám egész évben képesek lehetnek vonzani az utazókat, így alkalmasak arra, hogy a turizmusban alapvető problémát jelentő szezonális ingadozást mérsékeljék. A vidéki turizmus további pozitívuma, hogy a kínálat képes kapcsolatot teremteni a városi lakosság és a természet között. Mindemellett a vidéki turizmus képes egy adott társadalom hátrányos helyzetü rétegeinek befogadására is, figyelembe véve az általuk elkölthető diszkrecionális jövedelem alacsony mértékét. Az újonnan létre jövő kínálatok, célterületeivé válhatnak a környezettudatos, alternatív idegenforgalmi formáknak.

$\mathrm{Az}$ elmúlt hat-hét évtizedben, az európai államokban, egyre tisztábban érzékelhető a vidéki régiók gazdasági, társadalmi válsága. Ez a válság, karöltve azzal a gyengüléssel, amit a mezőgazdaság teherbíró-képességében tapasztalhattunk, a 
vidéki térségek népességmegtartó erejének erőteljes hanyatlását eredményezi (Fehér, 1993). Mivel a vidéki területek lakosságának városokba áramlását nem volt képes megállítani az agrárgazdaság támogatása, már az 1980-as években előtérbe került a turizmus, mint a vidéki gazdaság dinamizálásának eszköze, mivel a helyi erőforrások feltárásával pozitív eredményeket tudott felmutatni (Fructus, 1996; Gao et al., 2009). A területi fejlődésben lemaradó föként nem iparosodott, illetve alapvetően agrártérségek természeti környezete többségében ép, a lakosság által megőrzött tradíciók pedig a turizmus fejlesztésében vonzerőként szolgálhatnak (Virág, 2016). Ezen felül a turizmus mindig szorosan kapcsolódik a vidéki térségek fő gazdasági ágazatához, vagyis a mezőgazdasághoz. A mezőgazdaság által elöállított alapanyagokból készített helyi termékek alkalmazhatóak vonzóerőként, a térségben elérhető szolgáltatások minőségi elemeiként vagy akár reklámhordozóként is (Kovács, 1995; Csite, 1998). Így mondhatjuk, hogy a turizmus az agrártevékenységek kiegészítője. Mivel a vidéki turizmus a helyben élő és dolgozó lakosság által felkínált férőhely-kapacitására és az általuk nyújtott szolgáltatásokra szerveződik, a turisták által elköltött összegek közvetlenül helyben csapódnak le, így ezek a bevételek a helyi gazdaságot fogják élénkíteni. Tehát a vidéki turizmus, akármilyen turisztikai termék formájában jelenjen meg (pl.: falusi turizmus, zöldturizmus, kerékpáros turizmus stb.) pozitív, fejlesztő hatásokat fejthet ki egy leszakadásban lévő területen.

\section{A hazai turizmus teljesítménye a számok tükrében}

Amikor egy ország, mint hazánk is, fontolóra veszi a turizmusba történő invesztálást, az alapkérdés mindig az, hogy milyen potenciál rejlik az adott fogadóterületben, desztinációban, amelyet kihasználva infrastrukturális, társadalmi és gazdasági fejlődést lehet elérni. Turizmusról a definíció alapján akkor beszélünk, amikor a turista szokásos környezetét elhagyva, azon kívüli területen van jelen és a helyi értékesítők által kínált árukat és termékeket fogyasztja (UNWTO, 1989). A statisztika szempontjából viszont a turizmus megfigyelése sajátos feladat, mivel a turizmus szerteágazó gazdasági kapcsolatai miatt nagyon nehéz mérni a közvetlen és közvetett hatásait. A turizmus kereslete mindig addicionális az adott területen, térségben, országban a megszokott fogyasztáshoz viszonyítva. Ebből adódóan a turisztikai kereslet mindig kedvező, hiszen az addicionális fogyasztáson keresztül elösegíti a terület, a térség, az ország gazdasági növekedését. Ehhez adódik az a kedvező hatás, hogy a turisták olyan jövedelem elköltésével járulnak hozzá a meglátogatott térség, ország gazdasági növekedéséhez, amely máshol, a turista rezidens gazdaságában keletkezett (Nemes, 2008).

Ha egészében kezeljük Magyarországot, mint turisztikai egységet, akkor a jelenlegi teljesítményről az alábbiakat tudjuk elmondani. A magyar turizmus teljesítménye a Központi Statisztikai Hivatal adatai alapján 2019-ben a következö képen alakult. A beutazó turizmus esetében 2019-ben több mint 61 millió külföldi turistalátogatott Magyarországra, ami 6,47\%-os növekedést jelent 2018-hoz képest. A külföldi turisták összesen 2310,1 milliárd forintot költöttek hazánkban, ami 11,77\%-os növekedés a 2018-as adatokhoz viszonyítva. A több napra érkező turisták 
főbb célpontjai Budapest (49,0\%), Nyugat-Dunántúl (20,7\%) és a Balaton régiók $(10,4 \%)$ voltak, ahol a bevételek döntő többsége is realizálódott (KSH, 2020a).

Ha megtekintjük az aktuálisan elérhető település rangsort, akkor láthatjuk, hogy a külföldi turisták által hazánkban eltöltött vendégéjszakák alapján összeállított TOP10-es listán 8 település az említett régiókból került ki. Ám ha az 1. táblázatban mélyebben áttekintjük a 10 külföldiek által leglátogatottabb település közül kettő is a demográfiai és területi adatai alapján vidéki területen található.

1. táblázat: A leglátogatottabb magyarországi települések külföldi vendégéjszakák alapján

\begin{tabular}{|l|c|r|r|}
\hline \multicolumn{1}{|c|}{ Település } & $\begin{array}{c}\text { Vendégéjszakák } \\
\text { száma ezer föben }\end{array}$ & $\mathbf{2 0 1 8 / 2 0 1 7}$ & $\begin{array}{c}\text { Népsürüség } \\
\left(\mathbf{f o ́}^{\prime} / \mathbf{k m}^{2}\right)\end{array}$ \\
\hline 1. Budapest & 9032 & $+2,2 \%$ & 3347,02 \\
\hline 2. Hévíz & 691 & $-0,8 \%$ & 568,80 \\
\hline 3. Bük & 434 & $-4,6 \%$ & 171,57 \\
\hline 4. Hajdúszoboszló & 362 & $+4,5 \%$ & 99,47 \\
\hline 5. Balatonfüred & 288 & $-0,9 \%$ & 281,64 \\
\hline 6. Sárvár & 282 & $+5,0 \%$ & 228,88 \\
\hline 7. Györ & 233 & $+12,0 \%$ & 742,00 \\
\hline 8. Siófok & 221 & $-15,8 \%$ & 203,47 \\
\hline 9. Zalakaros & 149 & $+11,7 \%$ & 112,93 \\
\hline 10. Szeged & 147 & $+7,4 \%$ & 578,72 \\
\hline
\end{tabular}

Forrás: Saját szerkesztés KSH (2019a, 2019b) alapján

Mivel a vidéki területek besorolását korábban kistérségi szinten tették meg, és ma már a járások látják el ezt a funkciót, érdemes kitekinteni arra is, hogy az említett két település járásában mi is a helyzet. A Hajdúszoboszlói járásban, melynek Hajdúszoboszló a központja, 58 fö/ $\mathrm{km}^{2}$, a Nagykanizsai járásban, ahol Zalakaros is elhelyezkedik, 86 fö/ $\mathrm{km}^{2}$ a népsürüség.

A belföldi turizmust fókuszba helyezve és így a magyar lakosság többnapos belföldi utazásait tekintve 2019-ben a Központi Statisztikai Hivatal adatai alapján az elöző, 2018-as évhez képest 1,69\%-os csökkenés volt tapasztalható (1. ábra), ami még így is meghaladta az 59 millió napot. 2011-et alapul véve láthatjuk, hogy a belföldi utazásokon eltöltött idő csökkenő trendet mutat, hiszen 2011-hez viszonyítva 2019-ben 21,16\%-kal volt kevesebb a belföldi utazásokon eltöltött napok száma.

Ezzel a csökkenő trenddel szemben 2011 és 2019 között az tapasztalható a hazai utazásokhoz kapcsolódóan, hogy a lakosság költési hajlandósága folyamatosan növekszik (2. ábra). Míg 2011-ben a 142,5 milliárd forintot költöttek a magyarok a szabadidős utazásaik során, addig ez 2019-ben elérte a 222 milliárd forintot. A növekedés a bázis évhez képest 56,21\%-os. 


\section{1. ábra: A magyar lakosság többnapos belföldi utazásainak alakulása}

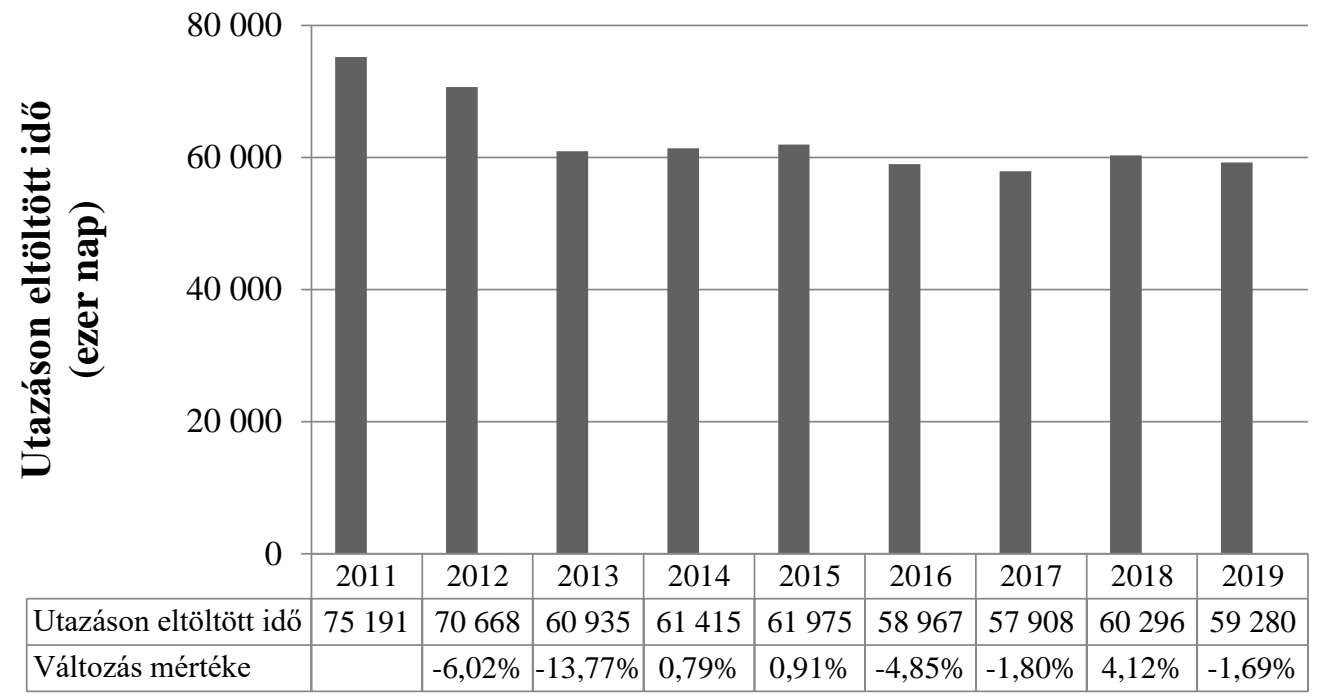

Forrás: Saját szerkesztés a KSH (2020b) alapján

2. ábra: A magyar lakosság többnapos belföldi utazásaihoz kapcsolódó költéseinek alakulása

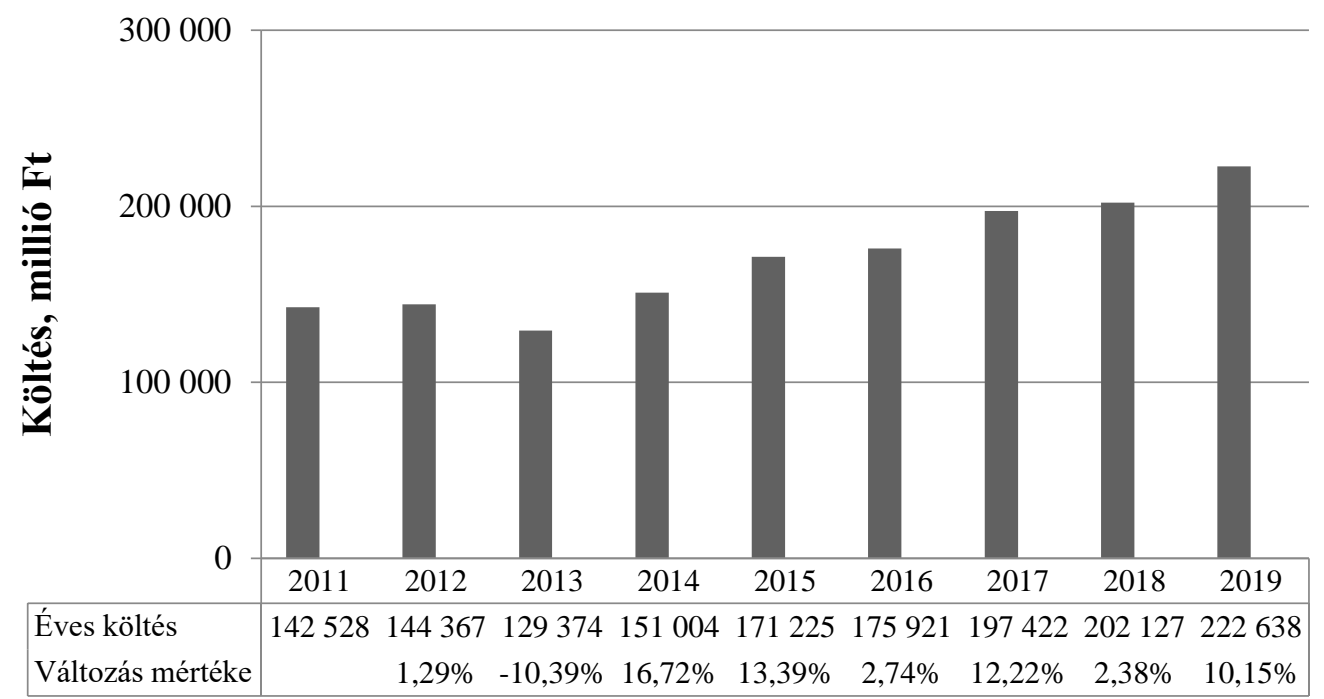

Forrás: Saját szerkesztés a KSH (2020b) alapján

A külföldiektöl eltéröen a belföldi turisták által eltöltött vendégéjszakák alapján összeállított TOP10 leglátogatottabb település között Hajdúszoboszló és Zalakaros mellett Gyula települése rendelkezik 150 fö $/ \mathrm{km}^{2}$ alatti népsürüséggel. Ez a szám a teljes Gyulai járásban 102 fö/ $\mathrm{km}^{2}$ (2. táblázat). 
2. táblázat: A leglátogatottabb magyarországi települések belföldi vendégéjszakák alapján

\begin{tabular}{|l|c|r|r|}
\hline \multicolumn{1}{|c|}{ Települések } & $\begin{array}{c}\text { Vendégéjszakák } \\
\text { száma ezer föben }\end{array}$ & $\mathbf{2 0 1 8 / 2 0 1 7}$ & $\begin{array}{c}\text { Népsürüség } \\
\text { (fö//km } \mathbf{~} \text { ) }\end{array}$ \\
\hline 1. Budapest & 1311 & $+8,3 \%$ & 3347,02 \\
\hline 2. Hajdúszoboszló & 626 & $+3,1 \%$ & 99,47 \\
\hline 3. Zalakaros & 488 & $+16,2 \%$ & 112,93 \\
\hline 4. Hévíz & 444 & $+2,5 \%$ & 568,80 \\
\hline 5. Balatonfüred & 441 & $+4,0 \%$ & 281,64 \\
\hline 6. Siófok & 440 & $-10,0 \%$ & 203,47 \\
\hline 7. Gyula & 382 & $+12,1 \%$ & 118,52 \\
\hline 8. Miskolc & 327 & $+12,7 \%$ & 668,02 \\
\hline 9. Eger & 315 & $-1,4 \%$ & 590,83 \\
\hline 10. Bük & 307 & $+6,5 \%$ & 171,57 \\
\hline
\end{tabular}

Forrás: Saját szerkesztés KSH (2019a, 2019b) alapján

Bár a Magyarországon található 3155 település és a huszonhárom budapesti kerület nem mindegyike kerülhet fel a 10 leglátogatottabb település listájára, ám sokuk így is jelentős haszonra tesz szert a turizmusnak köszönhetően kis mérete ellenére. Ehhez pedig az idegenforgalmi adót használják fel. A 2018. évi Nemzeti Adó-, és Vámhivatal adatai alapján Magyarországon közel 15 milliárd forintnyi ifa bevétel keletkezett, ami 2017-hez képest 9\%, 2014 óta pedig összesen 59\%-os növekedést jelent. A már korábban említett Hajdúszoboszló az 5. helyen áll, több mint fél milliárd forintnyi ifa-bevétellel. Zalakaros a 250-500 milliárd forintos bevétel kategóriába esett. Gyula települése bevétele alapján a 100 és 250 millió forint közötti kategóriába jutott be. Ám azért, hogy lássunk kisebb településeket, akiknek az életében és müködésében fontos bevételi forrás a turizmus, az 50-90 millió forintos kategóriában található Cserkeszőlö, a 25-49 milliós bevételi kategóriában található Bogács, Mátraszentimre, Balatongyörök. 18 és 24 millió forint közötti bevételt értek el Orfü, Kehidakustány, Parád és Kiskunmajsa települései is (Probáld, 2020).

A települési önkormányzatok idegenforgalmi adó felhasználásáról nincs rendelkezésre álló adatbázis (Nagy, 2013). Igaz a világhálóra számos település feltölti és így elérhetővé teszi a kellő ifá-val kapcsolatos információt, amelyek bár begyüjthetőek, de teljes körü elemzésre alkalmas adatbázis az így elérhető információk alapján nem építhető fel. Mindezek ellenére elmondható, hogy az ifa jelentősége települési szinten eltérő. Ebből fakadóan az ifa megítélése kétoldalú. Azok a települések, amelyek vonzóak a turisták körében, képesek arra, hogy az ifát teljes egészében vissza tudják forgatni a turizmusba. Ezzel szemben a kisebb települések, akik az idegenforgalmi adóval jóval kisebb bevételekre tesznek szert és ezzel egy időben forráshiánnyal is küzdenek, az ifát kényszerüségből saját közfeladataik ellátására fordítják (Barna-Papp, 2017). 
A munkavállalás tekintetében a turizmus területén hazánkat az alábbiak jellemzik. 2019-ben több mint 428 ezer föt foglalkoztattak a turizmushoz kapcsolódóan Magyarországon, ebből a szálláshely-szolgáltatás, vendéglátás ágazatban pedig 186,8 ezer fó állt alkalmazásban (KSH, 2020b).

Az iparágban jellemző a hétvégi munka és a hosszú müszakidők. Nagymértékü fizikai és pszicho-szociális terhelést jelentenek a turisztikai munkakörök. A sok nehézség ellenére számos vonzerőként szolgáló tényező található a turizmushoz kötődő szakmákban, mint a korrekt tulajdonos, a jó munkahelyi légkör, a megfelelő munkakörülmények. Emellett a munkával arányos kereset komoly megtartó erő lehet (Biermann, 2018).

Az eddig elért eredményekben azonban a 2020 -as rendkívüli vírushelyzet okoz egy komoly törést, amelynek a pontos következményeit még nem láthatjuk. A válsághelyzetet követően elképzelhető egy olyan növekedés, mint amit a 2008-as gazdasági világválság után is lehetett tapasztalni, de akár a klasszikus tömegturizmus háttérbeszorulásával is számolhatunk, amelynek eredményeképpen a vidéki, kevésbé ismert turisztikai helyszínek kerülnek középpontba.

\section{8. Összegzés}

Mivel maga a vidék végtelenül változatos gazdasági, társadalmi és környezeti értelemben egyaránt, ezért nem lehet elvetni annak szükségességét, hogy a vidéki, vagy vidékies területek fejlesztésében a turizmusnak is szerepet kell kapnia. Ma már az újraiparosítás, vagy a mezőgazdasági termelés növelése nem feltétlenül jár sikerrel akkor, amikor egy terület szenved a gazdasági szervezetek stagnálásától, a gazdasági aktivitás csökkenésétől, a helyi lakosság elvándorlásától, vagy a parlagon álló és hanyatló infrastruktúrától.

Egy jobban célzott, turizmus által vezérelt, szegénység enyhítési koncepció és egy hatékonyabb vidékgazdasági rendszer együttes alkalmazása képes lehet arra, hogy egy win-win helyzetet hozzon létre a turizmusfejlesztés és a vidéki növekedés között. Ezzel el lehetne érni a vidékfejlesztés azon célját, miszerint a helyi lakosság számára hosszú távon egy magasabb életszínvonalat kell biztosítani úgy, hogy az adott régióban ez egy magasabb fokú, tartós gazdasági növekedéssel párosuljon.

Akár urbánus, akár természeti közegben valósulnak meg a turisztikai szolgáltatások, a keletkező jövedelmek, a végbemenő társadalmi tudatosítási folyamat, a kapcsolódó területrendezések, infrastrukturális fejlesztések és megalkotott helyi érvényü rendeletek, vagy országos jogszabályok mind képesek arra, hogy egy adott térség leszakadásának mértékét csökkentsék, megállítsák, vagy akár egy növekvő pályára állítsák.

Ehhez az is hozzájárul, hogy Magyarországon a turizmust stratégiai ágazatként kezelik, és a gazdaság egyik motorjaként funkcionál. A teljes ágazat a multiplikátorhatást figyelembe véve biztosítja az ország által megtermelt bruttó hazai össztermék 13\%-át, a foglalkoztatottság területén pedig a közvetlen és közvetett hatásait összesítve a teljes munkavállalói állomány 13,2\%-át adja a turizmus (MTÜ, 2017). A kizárólag erre a szektorra kivetett adóból, az 
idegenforgalmi adóból, a helyi önkormányzatok több mint 15 milliárd forintnyi bevételre tesznek szert (Probáld, 2020).

Elmondhatjuk, hogy a turizmushoz kapcsolódóan végrehajtott fejlesztések emelik a helyiek életszínvonalát, kiegészítő jövedelmet szolgáltatnak számukra és hosszú távon is fenntartható módon segítik a perifériára sodródott területeket. A helyi erőforrások aktivizálásával a turizmus fejlesztési erőt vihet a helyi gazdaságba; támogathatja az agrártevékenységet, és kiegészítő jövedelmekhez juttatja a helyi önkormányzatot is. A vidéki turizmus fö vonzerőiként a természet közelsége, a még élő tradíciók (tárgyi, szellemi, kulturális, valamint termelési hagyományok), a vidéki életmód, az emberi interakciók és kapcsolatok emelhetők ki. Mindezek azonban nem egyetlen meghatározott turizmusváltozat alapját jelentik. Sokszínü, tájegységenként, településenként, de akár vendégfogadónként is eltérö a kínálat, így a turizmus számos típusának kialakulásához nyújt kiváló lehetőséget a vidéki turizmus. Ezért minden vidéki területen történő turisztikai irányú fejlesztéshez szükséges figyelembe venni a helyi térség addigi általános gazdasági és turisztikai teljesítményét, a rendelkezésre álló erőforrásait, helyi kapcsolatait és ezek alapján kell kidolgozni egy fejlesztési koncepciót, ami a tervezéstől, a megvalósításon és üzemeltetésen át, egészen az értékelésig és felülvizsgálatig minden lépésbe bevonja a helyi érdekcsoportokat.

\section{Irodalomjegyzék}

Akgün, A. A., Baycan, T., Nijkamp, P. (2015): Rethinking on sustainable rural development. European Planning Studies, 23 (4): 678-692.

Barke, M. (2004): Rural Tourism in Spain. International Journal of Tourism Research, 6 (3): 137149.

Beritelli, P., Bieger, T., Laesser, C. (2007): Destination governance. Using corporate governance theories as a foundation for effective destination management. Journal of Travel Research, 46: 96-107.

Biermann M (2018): Munkaerőhiány? Egy alkalmi vendéglátós tapasztalatai a Balatonnál. Munkaügyi Szemle, 61 (2): 60-62.

Buhalis, D. (2000): Marketing the competitive destination of the future. Tourism Management, 21: 97-116.

Cernea, M. M. (1994): A társadalomtudományi ismeretek a fejlesztési politikában és a projektekben. In: Madarász I. (szerk.): Szöveggyüjtemény a vidékfejlesztés szociológiája tantárgy tanulmányozásához. Gödöllői Agrártudományi Egyetem, Gödöllő. 67-80.

Cossío-Silva, F. J., Revilla-Camacho, M. Á., Vega-Vázquez, M. (2019): The tourist loyalty index A new indicator for measuring tourist destination loyalty. Journal of Innovation and Knowledge, 4 (2): 71-77.

Csatári B. (2004): A magyarországi vidékiségről, annak kritériumairól és krízisjelenségeiről. Területi Statisztika, 44 (6): 532-543.

Csita A. (1998): Regionális és vidékfejlesztés Észak-Korjalában. A falu, 13 (1): 75-81.

Dax, T. (1996): Defining rural areas - International comparisons and the OECD indicators. Rural Society, 6 (3): 3-18.

Dávid L., Tóth, G., Bujdosó, Z., Remenyik, B. (2011): The role of tourism in the development of border regions in Hungary. Romanian Journal of Economics, 32: 109-124.

Demir, E., Gozor, G. (2018): Does economic policy uncertainty affect Tourism? Annals of Tourism Research, 69: 15-17. 
Douglas, D. J. A. (2005): The restructuring of local government in rural regions: A rural development perspective. Journal of Rural Studies, 21: 231-246

Ellis, F., Biggs, S. (2001): Evolving Themes in Rural Development 1950s-2000s. Development Policy Review, 19 (4): 437-448.

Erdei F. (1971): Város és Vidéke. Szépirodalmi Könyvkiadó, Budapest

Farkas T. (2002): Vidékfejlesztés a fejlődéselméletek és a fejlesztési koncepciók tükrében. Tér és Társadalom, 16 (1): 41-57.

Fehér I. (1993): Vidékfejlesztés az Európai Közösségben. A falu, 8 (1): 7-21.

Font E. (1998): A vidék gondja globális, vagy lokális kérdés? A falu, 13 (3): 27-35.

Fructus, M. (ED.) (1996): Guide pratique des gestionnaires de routes du vin. EU Ouverture Reset Project. Université de Bordeaux 1., Bordeaux

Gao, S., Huang, S., Huang, Y. (2009): Rural Tourism Development in China. International Journal of Tourism Research, 11 (5): 439-450.

Gartner, W. C. (2004): Rural Tourism Development in the USA. International Journal of Tourism Research, 6 (3): 151-164.

Gunn, C. A. (1994): Tourism planning. Taylor and Francis, London

Haugland, S. A., Ness, H., Grønseth, B-O., Aarstad, J. (2011): Development of tourism destinations - An Integrated Multilevel Perspective. Annals of Tourism Research, 38 (1): 268-290.

Healey, P. (2015): Civil society enterprise and local development. Planning Theory \& Practice, 16 (1): 11-27.

Hoggart, K., Buller, H. (1994): Vidékfejlesztés. In: Madarász I. (szerk.) Szöveggyüjtemény a vidékfejlesztés szociológiája tantárgy tanulmányozásához. Gödöllői Agrártudományi Egyetem, Gödöllö, 28-38.

Horváth Gy. (2003): Az uniós tag Magyarország új kohéziós politikájának alapkérdései, In: Nagy E.Nagy G. (szerk.) Az Európai Unió bővitésének kihivásai - régiók a keleti periférián. Nagyalföldi Alapítvány, Békéscsaba, 26-32.

Hu, Y., Brent Ritchie, J. R. (1993): Measuring destination attractiveness: A contextual approach. Journal of Travel Research, 32: 25-34.

Jancsik A. (2007): A turizmus által hasznosítható erőforrások fogalma, köre és típusai In: Dávid L. (szerk.) Turisztikai eröforrások - A természeti és kulturális eröforrások turisztikai hasznositása. Perfekt Gazdasági Tanácsadó, Oktató és Kiadó Zrt., Budapest, 59-89.

Janvry, A., Sadoulet, E. (2007): Toward a territorial approach to rural development. Electronic Journal of Development and Agricultural Economics, 4 (1): 66-98.

Kis K. (2019): Gondolatok a vidékfejlesztés „rendszertanáról” - A teljesség felé... Jelenkori társadalmi és gazdasági folyamatok, 14 (3): 11-27.

Kis K. (2011): A vidék és a vidéki térségek meghatározásának európai vonatkozásai: történeti áttekintés az Európai Bizottság új város-vidék tipológiája apropóján. Jelenkori társadalmi és gazdasági folyamatok, 6 (1-2): 105-112.

Kovács A. D., Farkas, J. Zs., Perger, É. (2015): A vidék fogalma, lehatárolása és új tipológiai kísérlete. Tér és társadalom, 29 (1): 11-34.

Kovács D. (1995): A falusi turizmus helye a családi gazdálkodásban és az átalakuló mezőgazdaságban. A falu, 10 (2): 75-82.

Kovács T. (2000): Vidék, vidékfejlesztés, vidékpolitika. Gazdálkodás, 44 (3): 11-20.

Központi Statisztikai Hivatal (2020a): A Magyarországra tett külföldi többnapos utazások megoszlása a felkeresett turisztikai régió és a látogató nemzetisége szerint (2009-). <https://www.ksh.hu/docs/hun/xstadat/xstadat_eves/i_ogt007.html> (2020.03.17.)

Központi Statisztikai Hivatal (2020b): A többnapos belföldi utazások összefoglaló adatai (2008-). <https://www.ksh.hu/docs/hun/xstadat/xstadat_eves/i_ogt009.html> (2020.03.17.)

Központi Statisztikai Hivatal (2020b): A foglalkoztatottak száma nemzetgazdasági ágak, ágazatok szerint, nemenként - TEÁOR'08 (2008-). <http://www.ksh.hu/docs/hun/xstadat/xstadat_ eves/i_qlf005b.html> (letöltve: 2020.03.17.)

Központi Statisztikai Hivatal (2019a): Helyzetkép a turizmus, vendéglátás ágazatról, 2018. $<$ https://www.ksh.hu/docs/hun/xftp/idoszaki/jeltur/jeltur18.pdf> (2019.11.29.) 
Központi Statisztikai Hivatal (2019b): Magyarország közigazgatási helynévkönyve, 2019. január 1. $<$ https://www.ksh.hu/docs/hun/hnk/hnk_2019.pdf> (letöltve: 2019.10.13.)

Kulcsár L. (2018): Vidékfejlesztés és a helyi társadalom. Észak-magyarországi Stratégiai Füzetek, 15 (3): 4-12.

Kulcsár L. (2017): A vidékfejlesztés fogalmi bonyodalmai és bonyolult értékei. In: Kulcsár L. (szerk.) A vidékfejlesztés elméleti megközelitése: regionális és kulturális összefüggések. Kriterion Könyvkiadó, Kolozsvár, 77-127.

Liu, J., Nijkamp, P., Lin, D. (2017): Urban-rural imbalance and Tourism-Led Growth in China. Annals of Tourism Research, 64: 24-36.

M. Barna K., Papp, Zs. (2017): Az idegenforgalmi adó volumenének és felhasználásának területi különbségei. Területi Statisztika, 57 (2): 224-243

Magyar Turisztikai Hivatal (2005): Nemzeti Turizmusfejlesztési Stratégia 2005-2013. <https://20102014.kormany.hu/download/4/5c/20000/NemzetiTurizmusfejlesztesiStrategia.pdf\#! Document Browse> (2020.03.23.)

Magyar Turisztikai Ügynökség (2017): Nemzeti Turizmusfejlesztési Stratégia 2030. <https://www.kormany.hu/download/8/19/31000/mtu_kiadvany_EPUB_297x210mm\%20$\%$ 20preview.pdf $>$ (2020.03.23.)

Marton, G., Raffay, Z., Prisztóka, Gy., Raffay, Á., Kiss, R. (2016): A Dráva-mente, mint határmenti, periférikus tér turizmusfejlesztésének problémái. Turisztikai és Vidékfejlesztési Tanulmányok, 1 (2): $34-48$.

Michalkó G. (2002): Az idegenforgalmi régiók gazdaságélénkítő szerepének problematikája. Földrajzi Értesitö, 51 (1-2): 151-165.

Michalkó, G., Vízi, I. (2001): A turizmus, mint globalizációs jelenség Magyarországon. Iskolakultúra: Pedagógusok Szakmai-tudományos Folyóirata, 11 (11): 10-19.

Moseley, M. J. (2003): Rural Development: Principles and Practice. SAGE Publications, London.

Murphy, P., Pritchard, M., Smith, B. (2000): The destination product and its impact on traveler perceptions. Tourism Management, 21: 43-52.

Nagy M. (2013): Az idegenforgalom adózása rövid idegenforgalmi áttekintéssel, nemzetközi példákkal. Adó, 27 (12-13): 96-98.

Nemes A. (2008): A turizmus gazdasági jelentősége nemzeti és regionális szinten. Társadalom és Gazdaság, 30 (2): 285-296.

Nemes G. (2018): A társadalmi innováció és integrált vidékfejlesztés - két jó gyakorlat. Északmagyarországi Stratégiai Füzetek, 15 (3): 69-78.

Nemes G. (2000): Az Európai Unió vidékfejlesztési politikája - az integrált vidékfejlesztés lehetőségei. Közgazdasági Szemle, 47 (6): 459-474.

Németh Á., Vercse T., Dövényi, Z. (2014): A fejlettség térbeli egyenlőtlenségei Magyarországon az európai uniós csatlakozás után: egy külhoni módszer adaptálása. Területi Statisztika, 54 (4): $308-332$.

OECD (2018): Rural 3.0. A framework for rural development. Policy Note. <https://www.oecd.org/cfe/regional-policy/Rural-3.0-Policy-Note.pdf> (2020.02.24.)

OECD (2016): OECD Regional Outlook 2016: Productive Regions for Inclusive Societies. OECD Publishing, Paris.

OECD Directorate for Public Governance and Territorial Development (2011): OECD Regional Typology. <https://www.oecd.org/cfe/regional-policy/OECD_regional_typology_Nov2012. pdf> (2020.01.17.)

OECD (1996): Territorial Indicators of Employment: Focusing on Rural Development. Organisation for Economic Co-operation and Development, Paris.

OECD (1994): Creating Rural Indicators for shaping territorial policy. Organisation for Economic Co-operation and Development, Paris.

Oppermann, M. (2000): Tourism Destination Loyalty. Journal of Travel Research, 39 (1): 78-84.

Pearce, D. G. (1989): Tourist development. Longman Scientific \& Technical, New York.

Pitblado, J. R. (2005): So, What Do We Mean by „Rural”, “Remote,” and "Northern”? Canadian Journal of Nursing Research, 37 (1): 163-168. 
Probáld Á. (2020): Ezek a települések szedik a legtöbb idegenforgalmi adót. <https://turizmus.com/szabalyozas-orszagmarketing/telepulesi-ifa-toplistak-2018-1168043> (2020.04.03.)

Ramirez, R. (1999): Value co-production: Intellectual origins and implications for practice and research. Strategic Management Journal, 20: 49-65.

Ribeiro, M., Marques, C. (2002): Rural tourism and the development of less favoured areas - between rhetoric and practice. International Journal of Tourism Research, 4 (3): 211-220.

Rodríguez-Díaz, M., Espino-Rodríguez, T. F. (2008): A model of strategic evaluation of a tourism destination based on internal and relational capabilities. Journal of Travel Research, 46: 368380.

Sarudi Cs. (2003): Térség- és vidékfejlesztés. A magyar térgazdaság és az európai integráció. Agroinform Kiadó, Kaposvár.

UNWTO (1989): The Hague Declaration on Tourism. <https://www.eunwto.org/doi/pdf/10.18111/unwtodeclarations.1989.03.01> (2019.10.21.)

Varga-Nagy A. (2016): A vidéki területek helyzete a turizmus tekintetében. Stadia Mundi Economica, 3 (2): 101-107.

Vicsek T. (2003): Komplexitás-elmélet. Magyar Tudomány, 164 (3): 305-307.

Virág Á. (2016): A turisztikai együttmüködések gazdasági szerepe. Studia Mundi-Economica, 3 (2): $115-124$.

Walsh, J. (1996): Local development theory and practice: recent experience in Ireland. pp. In: Alden, J., Bolan, P. (szerk.): Regional Development Strategies: A European Perspective. Jessica Kingsley Publishers, London, 159-177. 